\title{
KONSOLIDASI DESENTRALISASI FISKAL MELALUI REFORMASI KEBIJAKAN BELANJA DAERAH BERKUALITAS
}

\author{
(Decentralization Fiscal Consolidation through Policy Reform of Local Quality Spending)
}

\author{
Bambang Juanda* dan Dedy Heriwibowo** \\ * Program Studi Ilmu Perencanaan Pembangunan Wilayah dan Perdesaan, \\ Jl. Kamper Wing II, Lantai 5, IPB Dramaga-Bogor, Email: bbjuanda@gmail.com \\ ** Bappeda Kabupaten Sumbawa, Jl. Garuda No. 1, Sumbawa Besar-NTB, \\ Email: dedyheriwibowo@gmail.com
}

Naskah diterima: 03 Maret 2016

Naskah direvisi: 07 Maret 2016

Naskah diterbitkan: 30 Juni 2016

\begin{abstract}
The implementation of fiscal decentralization in Indonesia did not entirely achieve a positive impact. The poverty problems, widening regional and individual disparities, low service quality of education, health, and infrastructure still dominates local problems. A policy to boost a qualified local spending for consolidation of fiscal decentralization in Indonesia is needed. This paper aims to define the qualified spending, identify regulatory problems, and provide recommendations to improve policies supporting the realization of qualified spending. A qualified spending policy is a government's efforts to allocate local spending based on priorities of regional development, so that is is used efficiently and effectively, timely, transparently, and accountably. However, there are still many current regulations which are not in line and impede the realization of qualified spending. Policy reform agenda supporting the realization of qualified spending should focus on aspects on strengthening the region in developing and implementing the budget priority, the simplification mechanism of budget discussions, implementation of medium term expenditure framework, development of list of Special Allocation Fund (DAK) to support the achievement of minimum service standard and national priority, more transparent and accountable budgeting of grants and social aid, as well as simplification and integration of the reporting system of local government. Keywords: spending quality, planning, budgeting
\end{abstract}

\begin{abstract}
Abstrak
Implementasi desentralisasi fiskal di Indonesia hingga saat ini belum sepenuhnya memberikan pengaruh positif. Permasalahan kemiskinan, kesenjangan antardaerah dan individu yang memburuk, rendahnya kualitas pelayanan pendidikan, kesehatan, infrastruktur masih mendominasi masalah daerah, sehingga diperlukan kebijakan yang mendorong terwujudnya belanja daerah yang berkualitas dalam rangka konsolidasi desentralisasi fiskal di Indonesia. Tulisan ini bertujuan untuk mendefinisikan belanja pemerintah daerah yang berkualitas, mengidentifikasi regulasi yang bermasalah, dan memberikan rekomendasi perbaikan kebijakan yang mendorong terwujudnya belanja berkualitas. Kebijakan belanja daerah yang berkualitas merupakan upaya yang dilakukan pemerintah agar belanja daerah dialokasikan sesuai dengan prioritas pembangunan daerah, yang digunakan secara efisien dan efektif, tepat waktu, transparan, dan akuntabel. Namun masih terdapat berbagai regulasi saat ini yang cenderung belum sinkron dan menghambat terwujudnya belanja daerah yang berkualitas. Agenda reformasi kebijakan yang mendukung terwujudnya belanja daerah yang berkualitas perlu ditekankan pada aspek penguatan daerah dalam menyusun dan melaksanakan prioritas anggaran, penyederhanaan mekanisme pembahasan anggaran, penerapan kerangka pengeluaran jangka menengah, alokasi DAK berdasarkan proposal kegiatan untuk mendukung pencapaian standar pelayanan minimal dan prioritas nasional, penganggaran hibah dan bansos yang lebih transparan dan akuntabel, serta penyederhanaan dan pengintegrasian sistem pelaporan pemerintah daerah.

Kata kunci: belanja berkualitas, perencanaan, penganggaran
\end{abstract}

\section{PENDAHULUAN}

\section{A. Latar Belakang}

Seiring konsolidasi desentralisasi fiskal di Indonesia, pemerintah diharapkan dapat mendorong terwujudnya belanja daerah yang berkualitas. Isu belanja berkualitas sangat relevan menjadi substansi yang diatur dalam revisi Undang-Undang No. 33 Tahun 2004 tentang Perimbangan Keuangan antara Pemerintah Pusat dengan Pemerintahan Daerah. Sebelumnya, pemerintah telah menetapkan berbagai regulasi pengelolaan keuangan daerah. Namun demikian, seringkali ditemukan permasalahan tumpang tindih dan ketidaksinkronan antar-peraturan perundangan, sehingga dalam pelaksanaan anggaran di daerah justru menghambat terwujudnya belanja daerah yang berkualitas (Juanda, et al., 2014).

Tulisan ini dibangun atas proposisi jika regulasi pengelolaan keuangan daerah telah sinkron maka belanja pemerintah daerah akan berkualitas. Belanja pemerintah daerah merupakan syarat perlu (necessary condition) dan regulasi yang sinkron dan harmonis menjadi syarat cukup (sufficient condition). Terpenuhinya kedua syarat ini menjadi dasar keberhasilan kebijakan desentralisasi fiskal seperti yang dilaporkan banyak peneliti (Bird and Vaillancourt, 1998; Xie, Zou, and Davoodi, 1999; Lin and Liu, 2000; Akai and Sakata, 2002). Kebijakan desentralisasi fiskal telah menjadi jalan keluar untuk 
mencapai efisiensi, efektivitas tata kelola, stabilitas makroekonomi, dan mengatasi kesenjangan pembangunan ekonomi. Belanja pemerintah dalam konteks desentralisasi fiskal juga berdampak positif terhadap pertumbuhan ekonomi pada setiap level pemerintahan dan secara konsisten mendorong maksimisasi pertumbuhan. Kebijakan desentralisasi fiskal juga dapat menopang pertumbuhan yang berkelanjutan melalui peningkatan efisiensi ekonomi dan kesejahteraan sosial. Kebijakan desentralisasi fiskal juga berhasil mendorong reformasi pembangunan perdesaan (rural reform), meningkatkan akumulasi kapital, dan mendorong perkembangan sektor swasta.

Implementasi desentralisasi fiskal di Indonesia hingga saat ini belum sepenuhnya memberikan pengaruh positif. Permasalahan kemiskinan, rendahnya kualitas pelayanan pendidikan, kesehatan, dan infrastruktur masih mendominasi masalah daerah (Nugraheni dan Priyarsono, 2012; Lisna, Sinaga, Firdaus, dan Sutomo, 2013). Demikian pula masalah disparitas pembangunan antarwilayah dan kesenjangan pembangunan manusia (Suwana dan Sulistiani, 2009; BPS, 2012; Bappenas, 2013). Bahkan Jaya (2005) telah menyebutkan bahwa lemahnya aturan main dalam pelaksanaan desentralisasi fiskal di Indonesia telah mendorong terjadinya disfungsional kelembagaan. Setelah lebih dari 15 tahun dimulainya desentralisasi fiskal pasca Orde Baru, pemerintah pusat perlu secara spesifik mendorong terwujudnya belanja berkualitas di daerah.

\section{B. Permasalahan}

Belanja berkualitas dalam konteks keuangan publik merupakan kata kunci yang masih jarang ditemukan dalam penelitian ekonomi. Padahal istilah tersebut sering digunakan dalam wacana publik, terutama dikaitkan dengan penyebab rendahnya kinerja pemerintah daerah. Penelusuran yang dilakukan Juanda, et al. (2014), mengungkapkan terdapat beragam pengertian berkaitan dengan belanja berkualitas sehingga diperlukan definisi standar untuk menyamakan persepsi publik. Definisi standar tersebut juga harus dapat mengakomodasi norma-norma yang termuat dalam landasan normatif pengelolaan keuangan daerah seperti yang tercantum dalam ketentuan peraturan yang berlaku.

Upaya mendorong perbaikan kualitas belanja pemerintah daerah sejalan dengan tantangan daerah menghadapi Masyarakat Ekonomi Asean (MEA) dengan memanfaatkan sebaik-baiknya kewenangan yang dimiliki untuk mempercepat terwujudnya kesejahteraan masyarakat melalui partisipasi aktif pemangku kepentingan di daerah, karena pemerintah daerah dianggap lebih tahu permasalahan dan kebijakan yang tepat untuk daerahnya dibandingkan pemerintah pusat (Juanda, 2016a). Masalah rendahnya kualitas belanja pemerintah daerah saat ini merupakan masalah serius untuk disikapi karena terjadinya penurunan laju pertumbuhan ekonomi daerah, perlambatan penurunan angka kemiskinan, ketimpangan wilayah dan antarindividu yang antara lain disebabkan oleh belanja daerah yang tidak sesuai dengan prioritas pembangunan daerah (Otonomi Tak Kunjung Sejahterakan Daerah, 2016). Oleh sebab itu diperlukan reformasi kebijakan desentralisasi fiskal dengan salah satu fokusnya bagaimana meningkatkan kualitas belanja pemerintah daerah (Juanda, 2016b).

Berdasarkan latar belakang tersebut, dapat dirumuskan masalah penelitian dalam bentuk pertanyaan penelitian sebagai berikut:

1) bagaimana definisi belanja berkualitas yang komprehensif sehingga menjadi standar rujukan untuk penelitian terkait dengan ini?

2) regulasi apa saja yang memengaruhi belanja berkualitas?

3) bagaimana kebijakan yang mendorong terwujudnya belanja berkualitas?

\section{Tujuan}

Secara umum tulisan ini bertujuan untuk membangun kesadaran bersama akan pentingnya reformasi kebijakan pemerintah dalam rangka mewujudkan belanja berkualitas di daerah. Secara spesifik tulisan ini bertujuan: (1) merumuskan definisi belanja berkualitas yang komprehensif, (2) mengidentifikasi regulasi yang memengaruhi belanja berkualitas, dan (3) merumuskan kebijakan yang mendorong terwujudnya belanja berkualitas.

\section{KERANGKA TEORI}

A. Desentralisasi Fiskal

Secara teoritis desentralisasi yang dijalankan Indonesia dalam tiga bentuk: desentralisasi politik, desentralisasi administratif, dan desentralisasi fiskal (Litvack and Seddon, 1999; Jaya, 2010). Desentralisasi politik merupakan mekanisme penyerahan wewenang pemerintahan dari pemerintah pusat kepada pemerintah daerah dalam rangka mengatur dan mengurus sendiri urusan pemerintahan dan kepentingan masyarakat setempat. Desentralisasi ini sering disebut sebagai otonomi daerah. Desentralisasi administratif adalah penyerahan wewenang administratif dari pemerintah pusat kepada pemerintah daerah sesuai asas dekonsentrasi, delegasi, dan devolusi. Dekonsentrasi adalah pemberian tanggung penyelenggaraan beberapa pelayanan, sedangkan delegasi dan devolusi berhubungan dengan perimbangan kepentingan 
pusat dan daerah. Desentralisasi fiskal merupakan penyerahan wewenang fiskal daerah dalam rangka menopang desentralisasi politik dan adminisitratif pemerintah daerah, yaitu wewenang dalam penerimaan dan belanja daerah. Desentralisasi fiskal di Indonesia lebih banyak dalam hal keleluasaan alokasi belanja daerah, sedangkan wewenang dalam penerimaan daerah telah dibatasi dalam UndangUndang No. 28 Tahun 2009 tentang Pajak Daerah dan Retribusi Daerah supaya menghindari ekonomi biaya tinggi (Juanda, et al., 2013).

Meskipun telah dilakukan berbagai penyempurnaan kebijakan, desentralisasi fiskal di Indonesia masih mempunyai berbagai kelemahan dan kekurangan, baik dalam tataran konsep maupun implementasinya. Masih terdapat peraturan yang saling berbenturan satu sama lain, masih terdapat perbedaan pendapat maupun perebutan kewenangan antarlevel pemerintahan dalam pengelolaan fiskal daerah, ataupun masih sering terjadi multi-tafsir dalam implementasi kebijakan di daerah. Hal ini disebabkan karena tidak adanya kesamaan persepsi mengenai desentralisasi fiskal di Indonesia (DJPK, 2009).

Meskipun pengelolaan keuangan daerah telah banyak berubah sesuai kebutuhan desentralisasi fiskal, namun berbagai standar internasional belum diadopsi penuh (Halim, 2013). Basis perhitungan anggaran masih menggunakan modified cash base ketimbang full accrual base; penilaian aset masih didasarkan pada biaya historis (historical cost) ketimbang nilai pasar (market value); penerapan sistem anggaran kinerja masih belum sepenuhnya berperan dalam pengambilan keputusan alokasi anggaran. Modified cash base (modifikasi basis kas) adalah sistem pencatatan transaksi keuangan berbasis kas dengan penerapan akrual pada akhir periode pelaporan. Pada sistem akuntansi ini, pendapatan daerah diakui pada saat kas diterima di kas daerah dan belanja diakui pada saat kas dikeluarkan dari kas daerah. Basis kas untuk pendapatan dan belanja tersebut akan menghasilkan penyusunan Laporan Realisasi Anggaran (LRA) dan Laporan Arus Kas (LAK), sedangkan pencatatan akrual pada akhir periode akan menghasilkan neraca. Adapun full accrual base (basis akrual penuh) adalah sistem pencatatan transaksi keuangan pada saat terjadinya pendapatan atau belanja walaupun kas belum diterima atau dikeluarkan. Sejalan dengan amanat Undang-Undang No. 17 Tahun 2003 tentang Keuangan Negara dan Undang-Undang No. 1 Tahun 2004 tentang Perbendaharaan Negara, pemerintah saat ini mulai menerapkan akuntansi berbasis akrual. $\mathrm{Hal}$ ini didasarkan atas pertimbangan bahwa basis akrual penuh dapat memberikan informasi keuangan yang lebih lengkap daripada basis lainnya, terutama untuk informasi piutang dan utang pemerintah. Selain itu, laporan keuangan berbasis akrual juga menyediakan informasi mengenai kegiatan operasional pemerintah, evaluasi efisiensi dan efektivitas, serta ketaatan terhadap peraturan.

Berbagai agenda tersebut masih menjadi proses jangka panjang yang perlu terus diupayakan pemerintah. Seiring perjalanan waktu, perkembangan situasi dan diterbitkannya berbagai peraturan pelaksanaan pengelolaan keuangan daerah, saat ini semakin dirasakan masalah ketidaksinkronan, tumpang tindih, atau disharmonisasi ketentuanketentuan yang berlaku seperti klasifikasi belanja langsung dan belanja tidak langsung yang diatur dalam regulasi pengelolaan keuangan daerah namun tidak diakui dalam regulasi standar akutansi pemerintah, regulasi menyangkut pendanaan pendidikan dasar belum sinkron dengan regulasi pembagian urusan pendidikan, dan berbagai tumpang tindih regulasi yang menyangkut isu-isu lintas sektoral seperti kemiskinan, tata ruang, dan lingkungan hidup (Juanda, et al., 2014) Masalah ini semakin mengemuka, menyebabkan terhambatnya penyerapan anggaran, masalah akuntabilitas dan tranparansi yang ditandai oleh opini hasil pemeriksaan Badan Pemeriksaan Keuangan (BPK) yang kurang baik (DJPK, 2014). Sebagai contoh, pada tahun 2008 terdapat 31 daerah (6 persen) yang mendapat opini Tidak Wajar (TW) dan 118 daerah dengan opini disclaimer atau Tidak Memberikan Pendapat (TMP), sedangkan pada tahun 2013 terdapat 2 provinsi dengan opini TMP, 52 kabupaten memperoleh opini TW dan TMP, dan 3 kota dengan predikat TMP. Kondisi ini dikhawatirkan akan menyebabkan gagalnya daerah membangun kapasitas pengelolaan keuangan yang memadai.

\section{B. Kapasitas Pengelolaan Keuangan Daerah}

Konsep penilaian kapasitas pengelolaan keuangan daerah telah dikembangkan oleh Bank Dunia dan Kementerian Dalam Negeri (ANTARAAusAID, 2011). Penilaian tersebut dilakukan terhadap 9 bidang strategis yang terkait dengan pengelolaan keuangan daerah, yaitu (1) kerangka peraturan perundangan-undangan daerah, (2) perencanaan dan penganggaran, (3) pengelolaan/penatausahaan kas, (4) pengadaan barang dan jasa, (5) akuntansi dan pelaporan, (6) sistem pengendalian internal (internal audit), (7) hutang dan investasi publik, (8) pengelolaan aset, dan (9) audit serta pengawasan eksternal.

Masing-masing bidang strategis di atas terdiri dari sasaran hasil (outcomes) dan indikator. Sasaran merupakan kondisi yang diharapkan, pencapaiannya ditunjukkan oleh indikator sasaran. Indikator sasaran 
merupakan penjabaran dari berbagai peraturan perundangan nasional, tuntutan peningkatan kualitas sumber daya manusia dan kelembagaan untuk menerapkan sistem pengelolaan keuangan yang baik. Namun penilaian kapasitas pengelolaan keuangan daerah belum dikaitkan dengan kualitas belanja daerah dan kepuasan pelayanan publik.

\section{Aturan Hukum Belanja Berkualitas}

Berkaitan dengan pengertian belanja daerah, ada beberapa peraturan perundangan yang bisa diacu, yaitu Undang-Undang No. 17 Tahun 2003 tentang Keuangan Negara, PP No. 58 Tahun 2005 tentang Pengelolaan Keuangan Daerah, dan Permendagri No. 13 Tahun 2006 tentang Pedoman Pengelolaan Keuangan Daerah. Ketiga peraturan perundangan tersebut memberikan pengertian belanja daerah sebagai kewajiban pemerintah daerah yang diakui sebagai pengurang nilai kekayaan bersih. Pengertian belanja daerah dapat pula didefinisikan sebagai semua pengeluaran pemerintah daerah pada suatu periode anggaran (Halim, 2013). Belanja daerah diprioritaskan untuk melaksanakan urusan pemerintahan yang menjadi kewenangan provinsi atau kabupaten/kota yang terdiri dari urusan wajib dan urusan pilihan yang ditetapkan berdasarkan ketentuan perundangan.

Terkait dengan pelaksanaan urusan yang menjadi kewenangan pemerintah provinsi atau kabupaten/ kota, pemerintah provinsi atau kabupaten/kota akan melaksanakan belanja daerah yang merupakan semua kewajiban pemerintah daerah yang diakui sebagai pengurang kekayaan bersih (ekuitas dana) dalam periode tahun anggaran yang bersangkutan. Dalam belanja daerah ini, pemerintah daerah tidak akan mendapatkan pembayaran kembali, baik pada tahun anggaran berjalan maupun pada tahun anggaran berikutnya. Lebih lanjut, sesuai PP No. 58 Tahun 2005 tentang Pengelolaan Keuangan Daerah, belanja daerah diprioritaskan untuk melindungi dan meningkatkan kualitas kehidupan masyarakat dalam upaya memenuhi kewajiban daerah yang diwujudkan dalam bentuk peningkatan pelayanan dasar, pendidikan, kesehatan, fasilitas sosial, dan fasilitas umum yang layak, serta mengembangkan sistem jaminan sosial. Manajemen belanja daerah merupakan bagian manajemen atau pengelolaan Keuangan Daerah yang tercermin dalam APBD, sehingga pengertian belanja daerah yang berkualitas adalah belanja daerah yang sesuai dengan yang diinginkan oleh PP No. 58 Tahun 2005 tersebut.

Dengan demikian kualitas belanja berarti suatu "ukuran" atas belanja yang mempunyai karakteristik dengan suatu derajat ekselensi yang tinggi. Sesuai dengan prinsip dalam Keuangan Negara bahwa semua yang berkaitan dengan keuangan harus didasari peraturan perundang-undangan yang berlaku maka karakteristik yang melekat pada kualitas belanja seharusnya juga berbasis peraturan perudangan yang berlaku. PP No. 58 Tahun 2005 Pasal 4 menyebutkan bahwa keuangan daerah dikelola secara tertib, taat pada peraturan perundangundangan, efisien, ekonomis, efektif, transparan, dan bertanggung jawab dengan memerhatikan asas keadilan, kepatutan, dan manfaat untuk masyarakat. Dengan demikian belanja berkualitas daerah/ APBD (termasuk belanja pusat/APBN) mempunyai atribut, yaitu (1) belanja yang tertib, (2) belanja yang taat pada peraturan perundang-undangan, (3) belanja yang efisien, (4) belanja yang ekonomis, (5) belanja yang efektif, (6) belanja yang transparan, dan (7) belanja yang dapat dipertanggungawabkan dengan memerhatikan asas keadilan, kepatutan, dan manfaat untuk masyarakat. Dari beberapa pendapat masyarakat dan dihubungkan dengan PP No. 58 Tahun 2005, maka secara jelas dapat dipahami makna normatif belanja berkualitas memiliki kaitan dengan pelayanan publik.

\section{Belanja Daerah dan Pelayanan Publik}

Belanja daerah yang berkualitas diharapkan dapat mendukung terselenggaranya pelayanan publik sesuai tujuan desentralisasi. Kebijakan desentralisasi dilakukan melalui pemberian otonomi seluas-luasnya memiliki dua tujuan utama. Tujuan pertama adalah tujuan kesejahteraan, yaitu menjadikan pemerintah daerah sebagai instrumen untuk meningkatkan kesejahteraan di tingkat lokal melalui pemberian pelayanan publik dan menciptakan daya saing daerah yang pada gilirannya akan menyumbang kepada kesejahteraan nasional. Tujuan kedua adalah tujuan politik, yaitu pemerintah daerah akan menjadi instrumen pendidikan politik di tingkat lokal yang kalau berhasil akan menyumbang kepada pendidikan politik nasional, untuk mendukung proses demokratisasi dalam mewujudkan masyarakat madani (Mendagri, 2012). Dalam pelaksanaannya, daerah memiliki kemampuan yang berbeda-beda untuk mencapai tujuan otonomi tersebut. Khususnya dalam hal pelayanan publik, pemerintah ingin memastikan agar pelayanan publik yang terkait dengan pelayanan dasar yang menjadi urusan wajib pemerintah daerah dapat diberikan secara merata dalam standar kelayakan tertentu. Menurut ketentuan PP No. 65 Tahun 2005 tentang Pedoman Penyusunan dan Penerapan Standar Pelayanan Minimal (SPM), SPM merupakan ketentuan mengenai jenis dan mutu pelayanan dasar yang berhak diperoleh setiap warga negara secara minimal. 


\section{METOdOLOGI}

\section{A. Data Penelitian}

Data penelitian terdiri dari data primer dan data sekunder dari hasil penelitian Juanda, et al. (2013), DJPK (2013) dan Juanda, et al. (2014). Data primer diperoleh langsung dengan metode survei dari responden yang berasal dari 8 daerah sampel pada bulan Juli sampai bulan Oktober 2014. Instrumen untuk pengumpulan data primer menggunakan kuisioner dan dilakukan pendalaman informasi melalui Focus Group Discussion (FGD). Responden penelitian terdiri dari unsur pemerintah daerah, seperti Tim Anggaran Pemerintah Daerah (TAPD), Bappeda, Satuan Kerja Pengelola Keuangan Daerah, dan Dinas Pendidikan serta DPRD, khususnya dari Komisi Pendidikan dan Badan Anggaran DPRD. Data sekunder berupa profil kuangan daerah yang diperoleh dari Dirjen Perimbangan Keuangan Kementerian Keuangan dan laporan hasil evaluasi laporan keuangan pemerintah daerah yang dilakukan Badan Pemeriksaan Keuangan (BPK).

\section{B. Pemilihan Daerah Sampel}

Pemilihan daerah sampel menggunakan metode purposive sampling, yaitu prosedur penarikan contoh berdasarkan pertimbangan tertentu, dalam hal ini menggunakan dua kriteria pertimbangan, yang terdiri dari (1) perencanaan dan penganggaran (baik dan biasa) terutama pada aspek alokasi belanja urusan wajib tiga pelayanan dasar yang mencakup pendidikan, kesehatan, pekerjaan umum, dan (2) kualitas pelayanan (baik dan biasa). Daerah sampel penelitian adalah Daerah Istimewa Yogyakarta dan Kabupaten Badung (Perencanaan Baik, Pelayanan Baik), Kota Makassar dan Provinsi Riau (Perencanaan Biasa dan Pelayanan Baik), Provinsi Kalimantan Timur dan Provinsi Bangka Belitung (Perencanaan Baik, Pelayanan Biasa), Kota Pekan Baru dan Kabupaten Lombok Timur (Perencanaan Biasa, Pelayanan Biasa).

\section{Metode Analisis}

Metode analisis deskriptif kualitatif digunakan untuk mengkaji perumusan dan definisi belanja berkualitas serta pengaruh masalah regulasi terhadap atribut belanja berkualitas. Metode analisis statistika deskriptif (kuantitatif) digunakan untuk mempelajari penilaian responden terhadap atribut dan indikator belanja berkualitas dan penilaian responden terhadap regulasi pengelolaan keuangan daerah.

\section{HASIL DAN PEMBAHASAN}

\section{A. Definisi Belanja Berkualitas}

Pendefinisian belanja berkualitas memiliki landasan normatif sebagaimana tercantum dalam peraturan perundang-undangan, baik yang mengatur keuangan negara maupun secara spesifik menyangkut pengelolaan keuangan daerah. PP No. 58 Tahun 2005 tentang Pengelolaan Keuangan Daerah menerangkan bahwa keuangan daerah dikelola secara tertib, taat pada peraturan perundang-undangan, efisien, ekonomis, efektif, transparan, dan bertanggung jawab dengan memerhatikan asas keadilan, kepatutan, dan manfaat untuk masyarakat. Atribut belanja berkualitas dalam PP tersebut merupakan penjabaran Undang-Undang No. 32 Tahun 2004 tentang Pemerintahan Daerah dan Undang-Undang No. 33 Tahun 2004 tentang Perimbangan Keuangan antara Pemerintah Pusat dan Pemerintahan Daerah, dan masih tetap relevan dengan UndangUndang No. 23 Tahun 2014 tentang Pemerintahan Daerah yang merupakan revisi Undang-Undang No. 32 Tahun 2004 tersebut. Undang-Undang No. 23 Tahun 2004 menyebutkan bahwa pemerintah daerah diwajibkan untuk mengelola dana secara efektif, efisien, transparan, dan akuntabel (Pasal 280). Atribut tersebut sejalan dengan ketentuan dalam Undang-Undang No. 17 Tahun 2004 tentang Keuangan Negara yang menyebutkan bahwa keuangan negara dikelola secara tertib, taat pada peraturan perundang-undangan, efisien, ekonomis, efektif, transparan, dan bertanggung jawab dengan memerhatikan rasa keadilan dan kepatutan (Pasal 3). Berdasarkan kajian regulasi tersebut, jelaslah bahwa atribut belanja berkualitas telah ada dalam undangundang yang bersifat umum maupun yang secara khusus mengatur pengelolaan keuangan daerah.

Pada praktiknya, pemahaman mengenai belanja berkualitas dari wacana yang berkembang digunakan dengan atribut yang berbeda-beda. Seperti pemikiran-pemikiran yang dilontarkan oleh pejabat publik pada saat itu, misalnya Menteri Perencanaan Pembangunan Nasional/Kepala Bappenas periode tahun 2009-2014 mengaitkan belanja berkualitas dengan dua hal, yaitu fokus alokasi pada prioritas dan meningkatkan efisiensi belanja. Lebih tajam lagi Direktur Eksekutif Bank Dunia, berpendapat bahwa untuk meredam dampak perlambatan ekonomi global saat ini, Pemerintah Indonesia harus memperbaiki kualitas pengeluaran. Tiga hal terkait belanja berkualitas adalah (1) prioritas pengeluaran pemerintah untuk kegiatan yang produktif; (2) fokus pada program pengentasan kemiskinan; (3) kegiatan ekonomi yang dapat membuka lapangan pekerjaan. Hal ini menjadi penting karena hasilnya dapat mengakselerasi pertumbuhan ekonomi. Anggota Komisi XI DPR RI periode tahun 2009-2014, menyoroti empat hal terkait kualitas belanja yang optimal: (1) desain ulang kebijakan subsidi energi yang lebih efektif dan efisien; (2) prioritas dan 
meningkatkan belanja modal terutama untuk proyek infrastruktur yang mendukung MP3EI dan MP3KI. Belanja pegawai diminimalisir dengan memperbaiki sistem pengelolaan dan kesejahteraan pegawai negeri dan pensiun; (3) peningkatan belanja negara untuk bantuan sosial dalam mewujudkan jaring pengaman sosial; (4) penerapan reward/punishment dalam penyerapan dan penggunaan anggaran di kementerian dan lembaga agar tidak menumpuk di kuartal ke empat. Demikian juga Menteri Pendayagunaan Aparatur Negara dan Reformasi Birokrasi periode tahun 2009-2014, berpendapat bahwa belanja berkualitas terkait dengan aspek transparansi dan akuntabilitas pengelolaan keuangan daerah serta diperlihatkan dari hasil pelaksanaan reformasi birokrasi, K/L/pemda seperti capaian opini WTP dari BPK, instansi yang LAKIP-nya baik, dan menurunnya Indeks Persepsi Korupsi (IPK). Kepala Badan Kebijakan Fiskal Kementerian Keuangan periode tahun 2002-2014, mengungkapkan bahwa dalam upaya memperbaiki belanja berkualitas, pemerintah menjaga agar subsidi energi tidak tumbuh terlalu tinggi.

Berdasarkan berbagai review regulasi dan wacana yang berkembang di publik, indikator belanja berkualitas tersebut selanjutnya dapat dikelompokkan dalam 5 atribut belanja berkualitas, yaitu (1) prioritas belanja daerah; (2) ketepatan alokasi belanja; (3) ketepatan waktu; (4) akuntabilitas dan transparansi; (5) efektivitas dan efisiensi belanja (cost efficiency and effectiveness). Kelima atribut tersebut sebagai latent variable kualitas belanja yang saling terkait.

Sesuai dengan "nature"-nya, anggaran merupakan sesuatu yang terbatas. Oleh sebab itu setiap perencanaan dan pengalokasian anggaran akan selalu dibatasi oleh ketersediaan anggaran.
Keterbatasan anggaran tersebut memunculkan "urutan pilihan" atau prioritas. Dalam bahasa manajemen keuangan hal tersebut dikenal sebagai "capital rationing". Belanja berkualitas tentu akan menempatkan atribut prioritas untuk dilaksanakan dengan disiplin tinggi. Kedisiplinan yang tinggi terhadap prioritas akan menentukan ketepatan alokasi anggaran seperti yang ditunjukkan oleh indikator besaran alokasi belanja modal, alokasi belanja subsidi, hibah, dan bansos, serta belanja pegawai. Jadi ketepatan alokasi merupakan salah satu atribut kualitas belanja. Selanjutnya, prioritas belanja yang telah ditentukan secara baik, dan kemudian dianggarkan tidak akan berarti jika anggarannya (APBD) tidak disusun tepat waktu, dan demikian pula jika realisasi belanja maupun pendapatan tidak tepat waktu. Jadi atribut ketepatan waktu merupakan hal yang tidak kalah penting dalam belanja yang berkualitas. Lebih jauh, belanja yang berkualitas dapat dipahami dengan jelas bahwa belanja tersebut memenuhi konsep 3E's (ekonomi, efisien, dan efektif). Untuk itu, maka atribut tersebut haruslah sejalan atau didukung dengan atribut ketepatan waktu dan ketepatan alokasi belanja. Selain itu, pastilah tuntutan agar belanja pemerintah yang dikelola harus transparan dan akuntabel, ekonomis, efisien, dan efektif. Jadi atribut transparansi dan akuntabilitas dapat dipahami sebagai salah satu atribut pada kualitas belanja. Keterkaitannya seperti ditunjukkan melalui Gambar 1. Berdasarkan pembahasan tersebut dapat dirumuskan definisi belanja berkualitas adalah belanja yang dialokasikan berdasarkan prioritas pembangunan daerah yang dilakukan secara efisien dan efektif, tepat waktu, transparan, dan akuntabel (Juanda, et al., 2014).

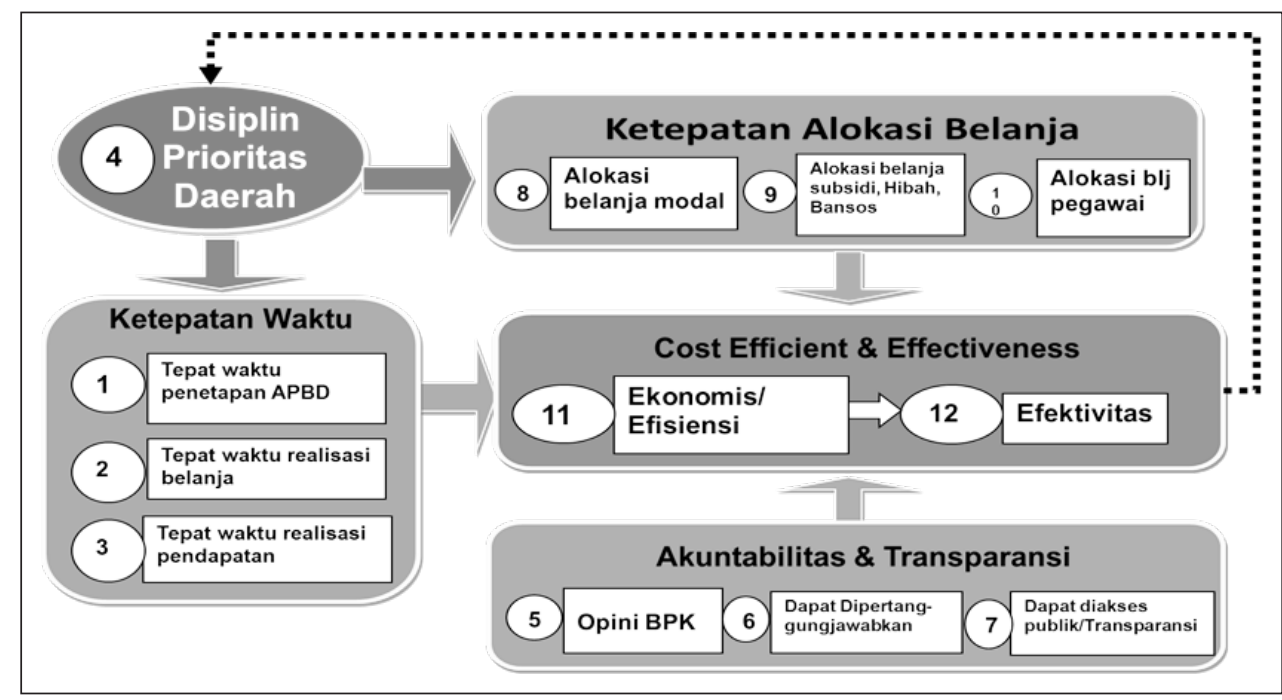

Sumber: Juanda, et al. (2014).

Gambar 1. Keterkaitan Antaratribut dan Indikator Belanja Berkualitas 


\section{B. Evaluasi dan Identifikasi Masalah Regulasi Pengelolaan Keuangan Daerah (PKD)}

Bagian ini mengidentifikasi masalah regulasi yang memengaruhi belanja berkualitas. Identifikasi masalah regulasi dirumuskan dari hasil FGD sebagai berikut:

1. Evaluasi Regulasi PKD

a. Jabatan Pengelolaan Keuangan Daerah

Penilaian responden terhadap lima aspek regulasi terkait jabatan PKD seperti terlihat di Gambar 2. Aspek terkait aspek kapasitas SDM merupakan yang paling bermasalah. Secara keseluruhan sebanyak 17,64 persen responden (provinsi 12,20 persen dan kabupaten/kota 22,72 persen) menyatakan bahwa regulasi yang ada belum mendukung terwujudnya belanja berkualitas. Adapun regulasi terkait struktur jabatan PKD telah dianggap memadai untuk mendukung belanja berkualitas.

b. Struktur APBD

Secara garis besar struktur APBD terdiri dari pendapatan, belanja, dan pembiayaan. Menurut penilaian responden, regulasi yang terkait dengan struktur belanja dianggap yang paling bermasalah, yaitu 30 persen $(28,9$ persen responden provinsi dan 30,95 persen responden kabupaten/kota). Masalah-masalah yang dikemukakan seperti (a) ketentuan tentang proporsi belanja langsung, belanja tidak langsung serta belanja modal belum memadai (Permendagri No. 13 Tahun 2006 tentang Pedoman Pengelolaan Keuangan Daerah dan penjabarannya); (b) pengelompokan belanja modal dan belanja barang/jasa masih belum sinkron antara regulasi penyusunan dan pelaporan; (c) belum jelas regulasi yang mengatur mengenai akomodasi aspirasi anggota DPRD dalam penyusunan anggaran; (d) regulasi bansos dan hibah belum jelas dan tegas sehingga cenderung digunakan untuk kepentingan kelompok tertentu; (e) penempatan dana Program Nasional Pemberdayaan Masyarakat (PNPM) pada kelompok belanja tidak langsung yang amat janggal; (f) pedoman alokasi belanja dalam pedoman penyusunan APBD belum selaras dengan ketentuan teknis kementerian/lembaga; (g) anggaran sertifikasi di alokasikan dalam APBD yang menyebabkan akan menambah porsi belanja pegawai; dan (h) alokasi anggaran BOS, ketentuan alokasi maksimal 20 persen untuk belanja pegawai tidak dapat memenuhi kebutuhan sekolah. Secara kuantitatif, penilaian persepsi mengenai regulasi terkait struktur APBD secara lengkap tersaji dalam Gambar 3.

c. Penyusunan Rencana Keuangan Daerah

Penyusunan anggaran satuan kerja perangkat daerah (SKPD) erat kaitannya dengan regulasi yang mengatur tentang penyusunan Rencana Kerja Pemerintah Daerah (RKPD), regulasi penyusunan dokumen Kebijakan Umum Anggaran dan dokumen Prioritas dan Plafon Anggaran Sementara (KUA dan PPAS) dan regulasi yang terkait dengan Rencana Kerja dan Anggaran (RKA). Ringkasan penilaian responden disajikan melalui Gambar 4.

Regulasi yang paling menghambat belanja berkualitas menurut responden adalah penyusunan RKPD $(18,61$ persen), setelah itu penyusunan KUA-PPAS (17,78 persen) dan terakhir penyusunan RKA-SKPD (6,82 persen). Temuan ini mengkonfirmasi rendahnya kualitas belanja daerah memang disebabkan oleh regulasi penyusunan rencana anggaran yang masih belum memadai.

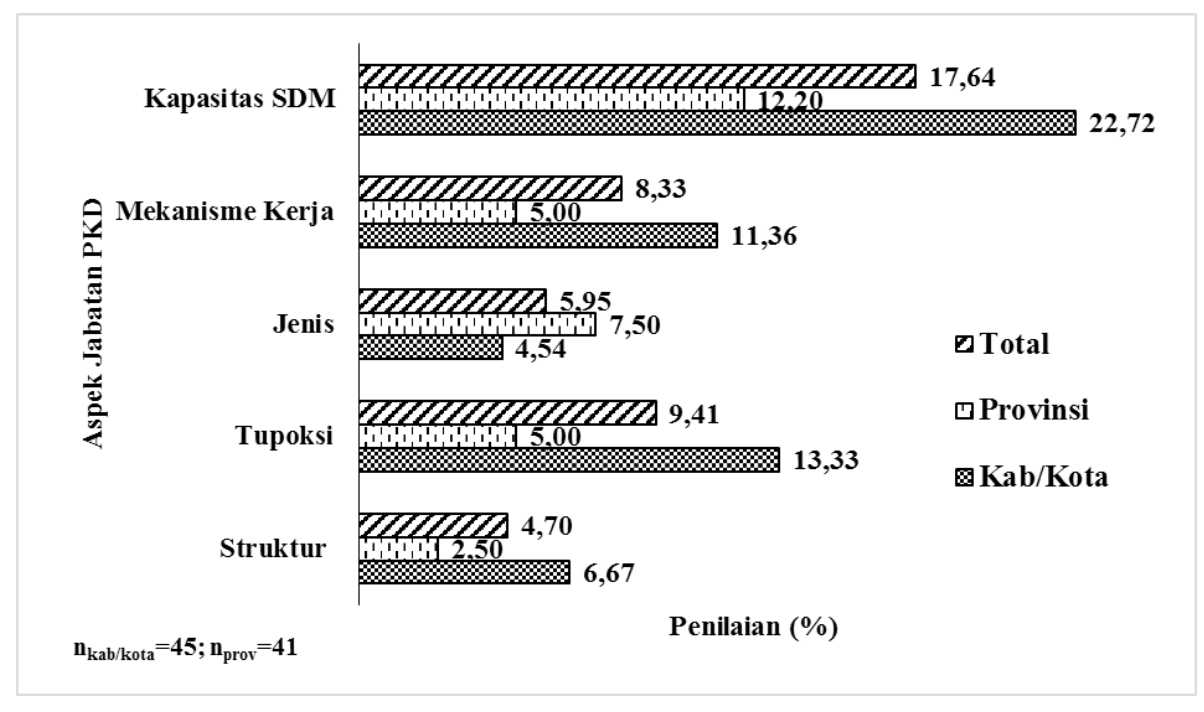

Sumber: Juanda, et al. (2014).

Gambar 2. Penilaian terhadap Regulasi Jabatan PKD yang Belum Mendukung Belanja Berkualitas 


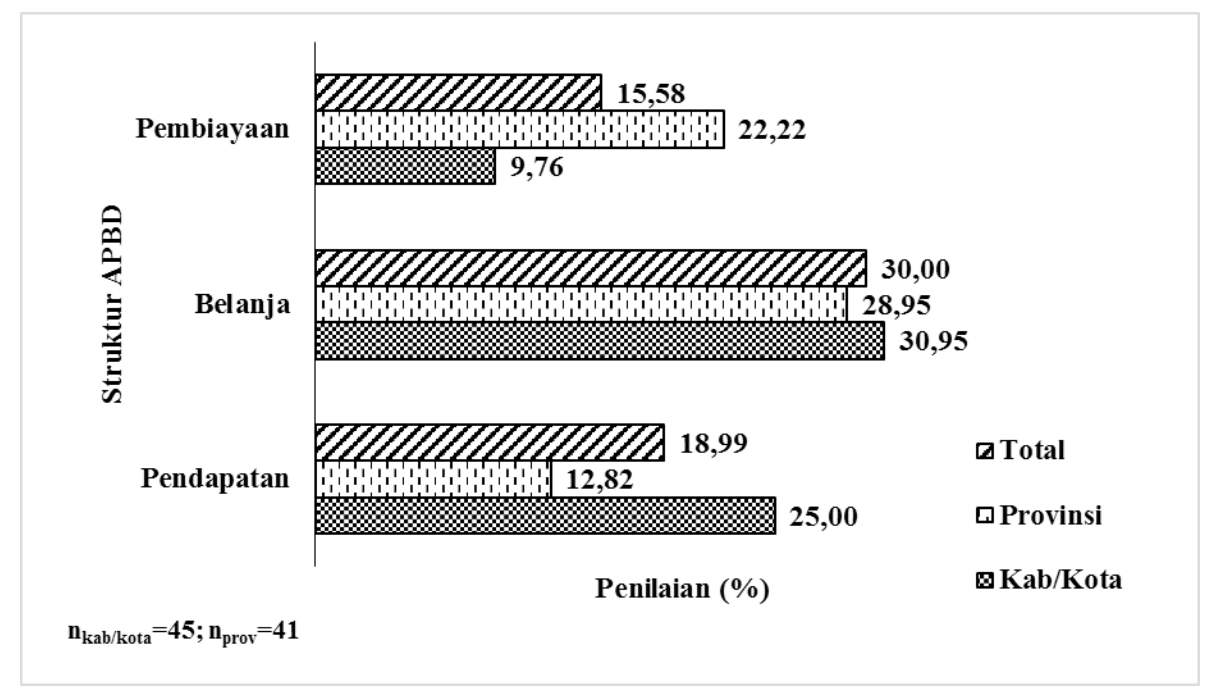

Sumber: Juanda, et al. (2014).

Gambar 3. Penilaian terhadap Regulasi Struktur APBD yang Belum Mendukung Belanja Berkualitas

d. Penyusunan dan Penetapan APBD

Responden juga ditanya apakah ketentuan penyusunan dan penetapan APBD telah mendorong terwujudnya rencana belanja yang berkualitas. Secara keseluruhan, 10,85 persen responden menyatakan bahwa regulasi pembahasan RAPBD belum mendukung belanja berkualitas. 7,23 persen responden menyatakan bahwa regulasi penyiapan RAPBD belum mendukung belanja berkualitas. Secara lengkap hasil analisis jawaban responden di Gambar 5 .

e. Evaluasi Aspek lainnya

Apakah regulasi mengenai pelaksanaan APBD telah mendorong terwujudnya rencana belanja yang berkualitas? Terhadap pertanyaan ini, responden yang berasal dari kabupaten/kota menjawab tidak setuju sebanyak 6,98 persen, dan sebanyak 11,11 persen dijawab oleh pemda provinsi dengan kategori yang sama (tidak setuju). Pertanyaan yang berkaitan dengan apakah regulasi mengenai penatausahaan APBD telah mendorong terwujudnya rencana belanja yang berkualitas? Sebanyak 2,38 persen tidak setuju, sedangkan responden dari pemda provinsi menilai tidak setuju sebesar 5,27 persen untuk pertanyaan ini. Jika respondennya digabung kabupaten/kota dan provinsi, jawaban tidak setuju sebanyak 8,86 persen. Apakah regulasi mengenai pelaporan APBD telah mendorong terwujudnya rencana belanja yang berkualitas? Sebanyak 13,93 persen, responden dari kabupaten/kota menjawab tidak setuju. Sementara responden dari pemda provinsi memberikan jawaban terhadap pertanyaan

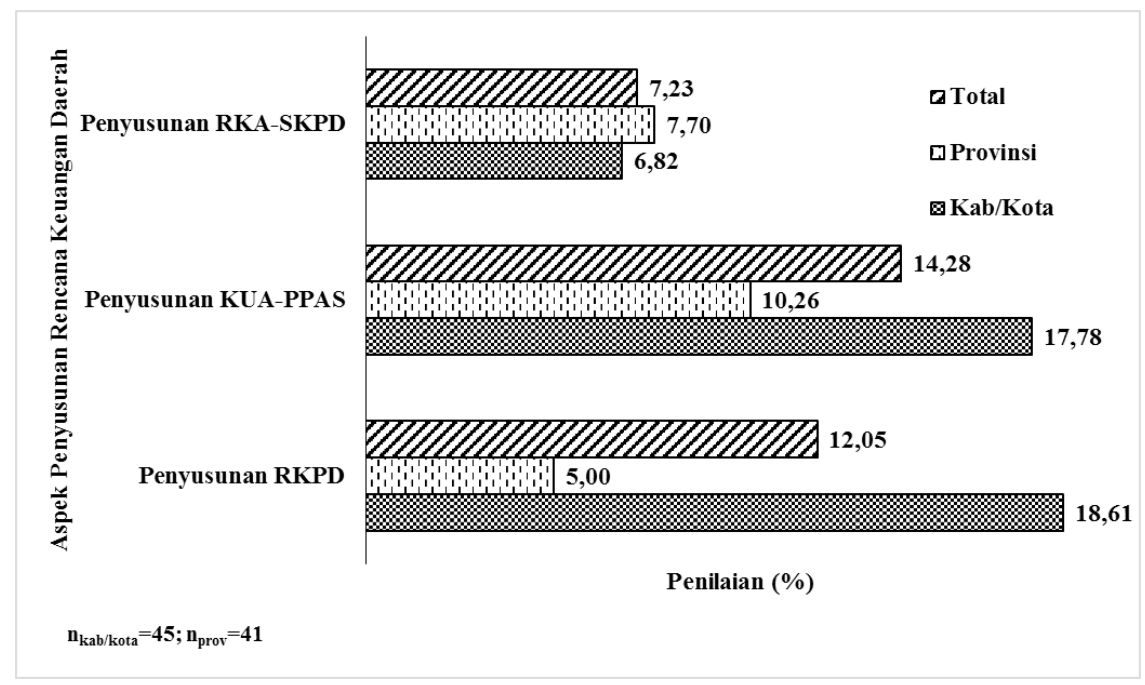

Sumber: Juanda, et al. (2014).

Gambar 4. Penilaian terhadap Regulasi Penyusunan Rencana Keuangan Daerah yang Belum Mendukung Belanja Berkualitas 


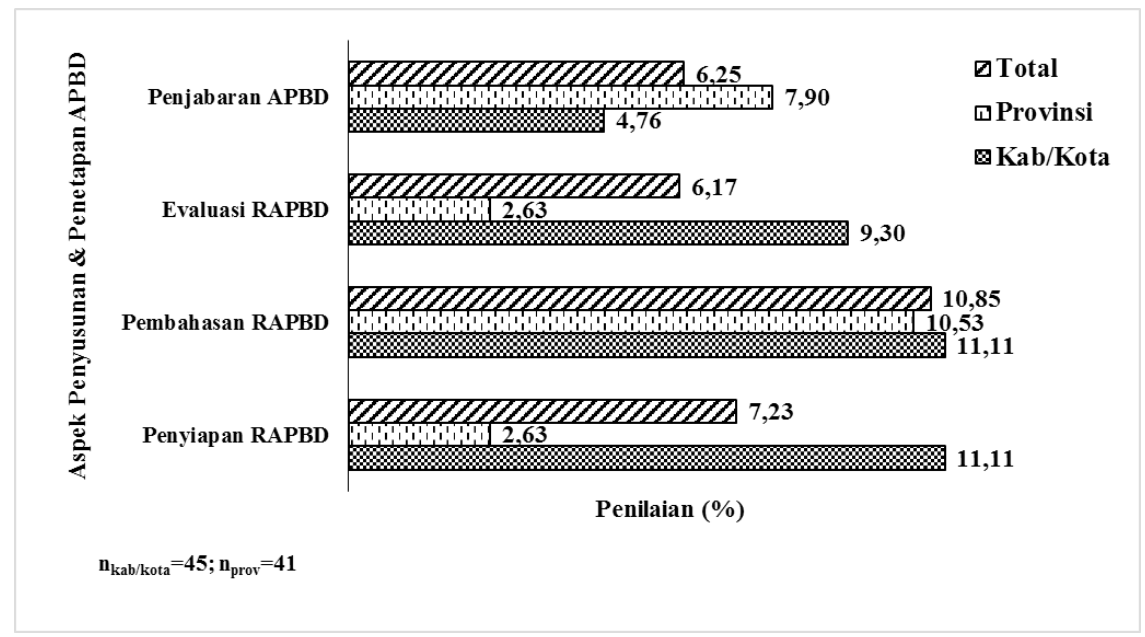

Sumber: Juanda, et al. (2014).

Gambar 5. Penilaian terhadap Regulasi Penyusunan dan Penetapan APBD yang Belum Mendukung Belanja Berkualitas

di atas sebanyak 7,90 persen menjawab tidak setuju. Untuk total responden menunjukkan angka 11,12 persen menjawab tidak setuju. Ringkasan penilaian ini disajikan melalui Gambar 6.

\section{Isu Utama Masalah Regulasi yang Memengaruhi Belanja Berkualitas}

Berdasarkan pembahasan sebelumnya teridentifikasi banyak masalah regulasi terkait perencanaan penganggaran dan atribut belanja berkualitas. Identifikasi regulasi tersebut masih masih bersifat umum sesuai informasi yang disampaikan peserta FGD. Analisis selanjutnya dilakukan pengelompokkan berdasarkan tema masalah. Tema masalah, atribut belanja berkualitas, dan regulasi terkait disajikan dalam Tabel 1.

Regulasi pendanaan pendidikan saat ini dapat menjadi masalah pada struktur biaya pendidikan, pengalokasian dana alokasi khusus (DAK), penggunaan biaya operasional sekolah (BOS), dan penerapan standar harga. Atribut belanja berkualitas yang terkait dengan masalah ini adalah prioritas daerah dan efisiensi/ekonomis dan efektivitas belanja.

Secara umum regulasi terkait laporan pemda mencakup regulasi yang mengatur tentang laporan keuangan, laporan kinerja instansi pemerintah, laporan penyelenggaraan pemerintahan daerah, dan regulasi yang mengatur batas waktu penyampaian laporan pemeriksaan BPK. Tema masalah ini terkait dengan atribut akuntabilitas dan transparansi belanja.

\section{Reformasi Kebijakan untuk Mewujudkan Belanja Berkualitas}

Reformasi kebijakan yang dimaksud di sini adalah perbaikan kebijakan yang perlu diambil untuk meningkatkan kualitas belanja pemerintah daerah. Perbaikan regulasi hanya salah satu bagian

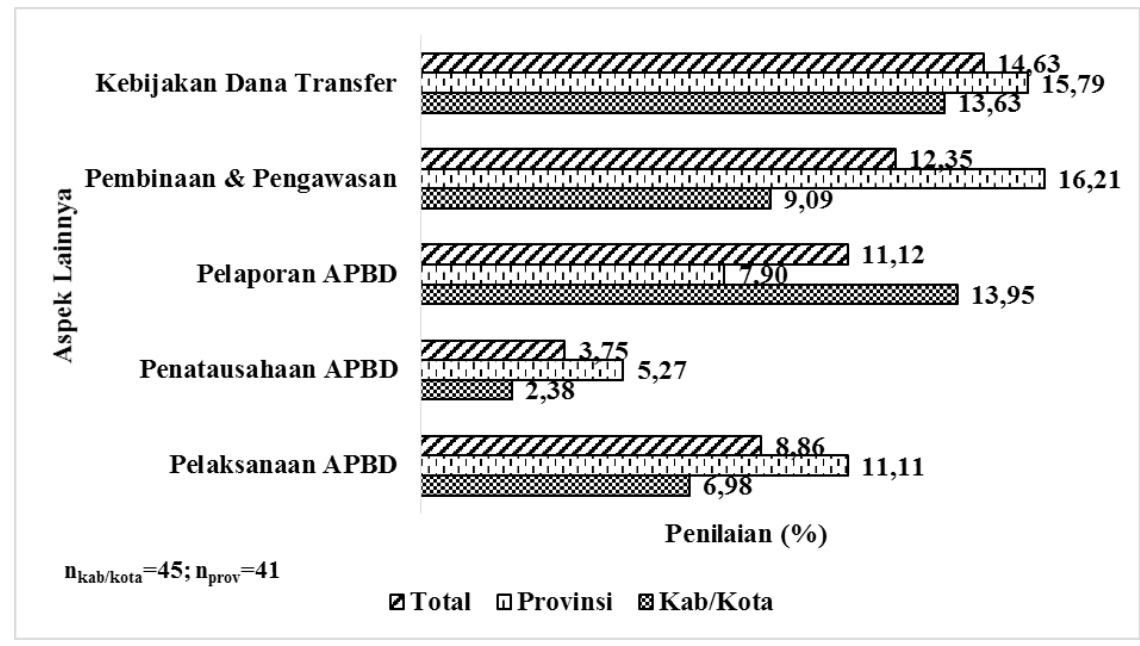

Sumber: Juanda, et al. (2014).

Gambar 6. Penilaian terhadap Regulasi Aspek Lainnya yang Belum Mendukung Belanja Berkualitas 
Tabel 1. Masalah Umum, Atribut Belanja Berkualitas, dan Regulasi Terkait dengan Tema Masalah

\begin{tabular}{|c|c|c|c|}
\hline No. & Isu Masalah & $\begin{array}{l}\text { Atribut Belanja } \\
\text { Berkualitas }\end{array}$ & $\begin{array}{c}\text { Regulasi Terkait dengan } \\
\text { Tema Masalah }\end{array}$ \\
\hline 1. & $\begin{array}{l}\text { Dokumen perencanaan } \\
\text { dan penganggaran (RKPD, } \\
\text { KUA-PPAS dan APBD) }\end{array}$ & $\begin{array}{l}\text { - } \quad \text { Prioritas daerah } \\
\text { - Ketepatan waktu } \\
\text { - Ketepatan alokasi }\end{array}$ & $\begin{array}{l}\text { - PP No. } 58 \text { Tahun } 2005 \text { Pasal } 34 \text { dan } 35 \\
\text { - Permendagri No. } 59 \text { Tahun } 2007 \text { Pasal 83, 87, dan } 88\end{array}$ \\
\hline 2. & $\begin{array}{l}\text { Pembagian urusan } \\
\text { (kewenangan) dengan } \\
\text { regulasi pencapaian } \\
\text { Standar Pelayanan } \\
\text { Minimal (SPM) }\end{array}$ & $\begin{array}{l}\text { - } \text { Prioritas daerah } \\
\text { dan efektivitas } \\
\text { belanja } \\
\text { - Ketepatan alokasi }\end{array}$ & $\begin{array}{l}\text { PP No. } 38 \text { Tahun } 2007 \text { yang telah dikukuhkan dalam lampiran } \\
\text { UU No. } 23 \text { Tahun } 2014 \text { mengenai pembagian urusan } \\
\text { pemerintahan bidang pendidikan tidak sinkron dengan PP No. } \\
47 \text { Tahun } 2008 \text { tentang Wajib Belajar Pasal } 4 \text { dan PP No. } 48 \\
\text { Tahun } 2008 \text { tentang Pendanaan Pendidikan Pasal } 21\end{array}$ \\
\hline 3. & Pendanaan pendidikan & $\begin{array}{l}\text { - } \text { Prioritas daerah } \\
\text { - } \text { efisiensi/ekonomis } \\
\text { dan efektivitas } \\
\text { belanja }\end{array}$ & $\begin{array}{l}\text { Permendiknas No. } 15 \text { Tahun } 2010 \text { tentang SPM Pendidikan } \\
\text { Dasar di Kabupaten/Kota Jo Permendikbud No. } 23 \text { Tahun } 2013 \\
\text { Pasal 2, Permendiknas ini tidak sinkron dengan PP No. } 47 \text { Tahun } \\
2008 \text { tentang Wajib Belajar dan PP No. } 48 \text { Tahun } 2008 \text { tentang } \\
\text { Pendanaan Pendidikan }\end{array}$ \\
\hline 4. & Hibah dan bantuan sosial & $\begin{array}{l}\text { - } \text { Ketepatan alokasi } \\
\text { - } \text { trantabilitas dan } \\
\text { transpansi }\end{array}$ & $\begin{array}{l}\text { Permendagri No. } 32 \text { Tahun } 2011 \text { Pasal } 1 \text { poin 14, 15, dan 16; } \\
\text { Penganggaran hibah: Pasal 8, 9, 10, dan 11; dan Penganggaran } \\
\text { Bansos: Pasal 27, 28, 29, dan } 30\end{array}$ \\
\hline 5. & $\begin{array}{l}\text { Pelaporan pemerintah } \\
\text { daerah }\end{array}$ & $\begin{array}{l}\text { Akuntabilitas dan } \\
\text { transparansi }\end{array}$ & - \\
\hline
\end{tabular}

Sumber: Juanda, et al. (2014).

kecil dari banyak upaya yang harus dilakukan untuk meningkatkan kualitas belanja. Pembenahan regulasi dimaknai sebagai bagian dari perbaikan aturan main (rules of the game), namun banyak aturan lain yang digunakan (rules in use) para pemangku kepentingan (Ostrom, 2005). Upaya pembenahan sebaiknya dilakukan dalam lingkup yang lebih luas melalui pembenahan kelembagaan (institutions) yang akan memengaruhi perilaku pengelolaan keuangan daerah. Kajian ini memberikan ilustrasi yang lebih jelas mengenai perbaikan aturan formal yang berperan penting dalam menentukan perilaku aktor pengelola keuangan daerah.

1. Perbaikan Mekanisme Pembahasan dan Penetapan Dokumen Perencanaan Anggaran

Dalam aturan yang berlaku saat ini, mekanisme pembahasan hingga penetapan anggaran amat panjang baik dari segi tahapan maupun waktu yang diperlukan. Mekanisme pembahasan ini mengandung masalah, antara lain:

a. Perkiraan anggaran yang dimuat dalam rancangan Kebijakan Umum Anggaran (KUA) dan Prioritas serta Plafon Anggaran Sementara (PPAS) yang dihasilkan dari Rencana Kerja Pemerintah Daerah (RKPD) masih bersifat indikatif (belum didasarkan atas perhitungan yang detail). Akibatnya banyak terjadi koreksi saat perkiraan anggaran tersebut dijabarkan dalam Rencana Kerja dan Anggaran Satuan Kerja Perangkat Daerah (RKA-SKPD); b. Mekanisme pembahasan KUA dan PPAS yang berlaku saat ini cenderung mendistorsi prioritas yang telah ditetapkan dalam RKPD;

c. Nota kesepakatan KUA dan PPAS dianggap belum memiliki kekuatan hukum mengikat, sehingga pada saat pembahasan rancangan peraturan daerah (raperda) Anggaran Pendapatan dan Belanja Daerah (APBD) cenderung mengabaikan nota kesepakatan yang telah disusun;

d. Sebagian besar daerah menyusun RKA-SKPD sebelum pengajuan KUA dan PPAS ke DPRD, cara ini membantu mereka mendapatkan argumentasi yang memadai bila ditanyakan dasar perhitungan plafon anggaran yang diusulkan; dan

e. Mekanisme pembahasan saat ini panjang dan rumit karena harus dilakukan beberapa tahap dari pemda (Rancangan KUA-PPAS) ke DPRD (pembahasan rancangan KUA-PPAS menjadi KUA-PPAS), kemudian ke pemda untuk menyusun RKA-SKPD menjadi RAPBD, dan dibawa ke DPRD untuk pembahasan RAPBD. Gambar 7 menggambarkan ringkasan mekanisme penyusunan dokumen perencanaan dan penganggaran.

Gambar 8 merupakan mekanisme alternatif yang diusulkan untuk mengatasi masalah yang muncul dari mekanisme yang berlaku sekarang dengan beberapa keuntungan antara lain: 


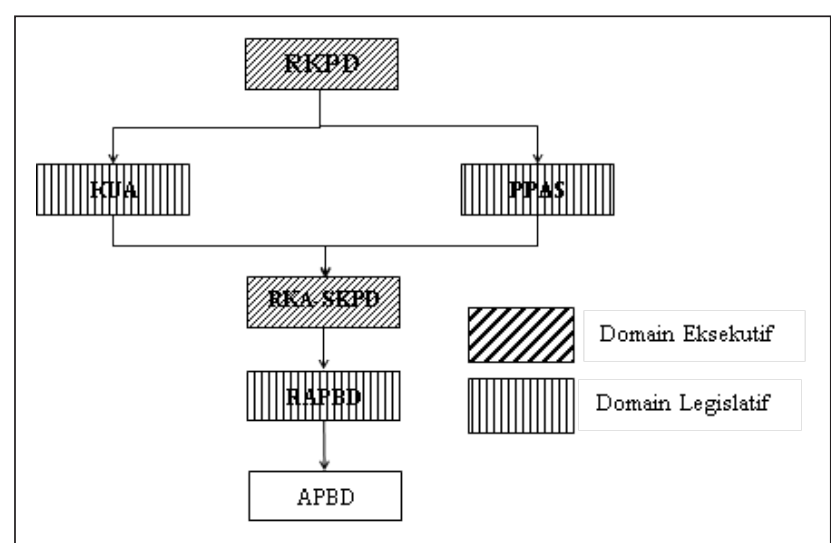

Sumber: Juanda, et al. (2014).

Gambar 7. Mekanisme Penyusunan Dokumen Perencanaan dan Penganggaran yang Berlaku Sekarang

a. Menyederhanakan mekanisme penyusunan anggaran dalam dua tahap: tahap I dan tahap II. Tahap I merupakan domain eksekutif, penyusunan RKPD, KUA, PPAS hingga RKA-SKPD dilakukan secara simultan. Cara ini memudahkan pemerintah daerah menjabarkan prioritas daerah dalam RKPD hingga ke tingkat RKASKPD sehingga meminimalisir potensi gangguan dibandingkan mekanisme lama. Setelah RKPD ditetapkan oleh kepala daerah, selanjutnya RKPD beserta rancangan KUA, PPAS dan RAPBD disampaikan kepada DPRD untuk dibahas dalam pembahasan tahap II. Pembahasan tahap II merupakan domain legislatif, pembahasan rancangan KUA, PPAS, dan RAPBD dilakukan secara simultan dalam satu masa sidang. Menyatukan pembahasan ketiga dokumen tersebut dalam tahap II dimaksudkan agar anggota DPRD memiliki pemahaman yang utuh mengenai logika yang berawal dari penyusunan rencana dalam RKPD dan berujung pada pengalokasian anggaran dalam APBD.

b. Mekanisme yang diusulkan tersebut dapat menghilangkan kontroversi kedudukan hukum KUA dan PPAS sebagai acuan penyusunan raperda APBD. Saat ini nota kesepakatan KUA dan PPAS dianggap tidak memadai sebagai landasan penyusunan peraturan daerah tentang APBD. Ketiga dokumen hasil pembahasan di tahap II menjadi bagian tak terpisahkan dari peraturan daerah tentang APBD.

\section{Perbaikan Mekanisme Pendanaan Pendidikan}

Berdasarkan hasil FGD, terungkap bahwa pemerintah provinsi tidak memiliki kewenangan untuk membiayai pendidikan dasar, karena mereka mengacu kepada PP No. 38 Tahun 2007 tentang Pembagian Urusan antara Pemerintah, Pemerintah Daerah Provinsi dan Pemerintah Daerah Kabupaten/ Kota, dan telah dikukuhkan dalam Undang-Undang

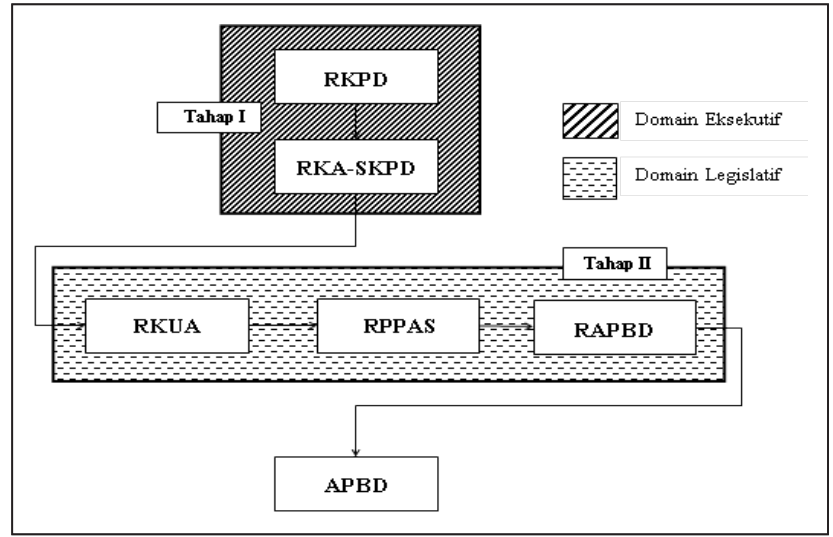

Sumber: Juanda, et al. (2014).

Gambar 8. Usulan Alternatif Perbaikan Mekanisme Penyusunan Dokumen Perencanaan Anggaran

No. 23 Tahun 2014 tentang Pemerintahan Daerah. Namun kondisi di lapangan ditemukan bahwa permasalahan pendidikan dasar sebaiknya masih menjadi tanggung jawab bersama mengingat kendala yang dihadapi kabupaten/kota terutama dalam penyediaan guru dan infrastruktur pendidikan dasar. Tanggung jawab bersama ini sejalan dengan semangat PP No. 47 Tahun 2008 tentang Wajib Belajar Pasal 4 dan PP No. 48 Tahun 2008 tentang Pendanaan Pendidikan Pasal 21.

Solusi jangka pendek diperlukan jalan tengah yang berorientasi pemenuhan anggaran pendidikan dasar di daerah. Prinsipnya pendanaan pendidikan dasar bersifat cost sharing antara pemerintah pusat, provinsi, dan kabupaten/kota. Pola cost sharing telah dipraktekkan pada beberapa daerah seperti di Provinsi NTB melalui anggaran beasiswa miskin, Provinsi DKI Jakarta melalui instrumen Kartu Jakarta Pintar (KJP), di Provinsi Sulawesi Selatan dan Provinsi Kalimantan Timur melalui instrumen BOS Daerah. Daerah lain seperti Provinsi Riau penyaluran cost sharing melalui instrumen bantuan keuangan (bankeu).

\section{Perbaikan Regulasi Standar Pelayanan Minimal (SPM)}

Menarik untuk dicermati bahwa tidak semua peraturan Kementerian/Lembaga Non Departemen yang menangani urusan wajib pemerintahan daerah menerbitkan SPM untuk setiap level pemerintahan daerah. Ada SPM yang hanya mencakup kabupaten/ kota saja sebagai pelaksanaanya, namun ada juga SPM yang pelaksanaannya termasuk pemerintah provinsi, misalnya jenis pelayanan dasar rumah layak huni dan terjangkau. Perbandingan regulasi SPM Pendidikan terlihat di Tabel 2. Dari segi kewenangan, semua level pemerintahan memiliki konkurenitas kewenangan namun ketika berbicara pemenuhan SPM sebagian besar pemenuhannya menjadi tanggung jawab pemerintah kabupaten/ 
kota. Kondisi inilah yang membingungkan bagi kabupaten/kota. Ilustrasi yang lebih konkrit dapat dilihat di SPM Pendidikan. Sesuai Peraturan Menteri Pendidikan Nasional (Permendiknas) No. 15 Tahun 2010 tentang Standar Pelayanan Minimal Bidang Pendidikan dan Peraturan Menteri Pendidikan dan Kebudayaan (Permendikbud) No. 23 Tahun 2013 tentang Perubahan Permendiknas No. 15 Tahun 2010 tentang SPM pendidikan dasar di kabupaten/ kota sedangkan provinsi hanya bertugas untuk melakukan monitoring dan evaluasi. Akibatnya pemerintah provinsi kesulitan dalam mengalokasikan anggaran pendidikan karena tidak menjadi tanggung jawabanya. Kondisi ini kontradiktif dengan kebutuhan pendanaan pendidikan. Beberapa daerah provinsi mengimplementasikan kebijakan afirmatif untuk pengalokasian anggaran pendidikan melalui mekanisme bantuan keuangan, hibah, dan bantuan sosial (bansos).

Tabel 2. Perbandingan Regulasi SPM Pendidikan

\begin{tabular}{|c|l|l|l|}
\hline \multirow{2}{*}{ No. } & \multirow{2}{*}{$\begin{array}{c}\text { Jenis } \\
\text { Pelayanan }\end{array}$} & \multicolumn{1}{|c|}{ Saat ini } & \multicolumn{1}{|c|}{$\begin{array}{l}\text { Alternatif } \\
\text { Perbaikan }\end{array}$} \\
\cline { 3 - 4 } 1. & $\begin{array}{l}\text { Pelayanan } \\
\text { di tingkat } \\
\text { kabupaten/ } \\
\text { kota } \\
\text { (14 indikator) }\end{array}$ & $\begin{array}{l}\text { Sepenuhnya } \\
\text { tanggung jawab } \\
\text { kabupaten/kota }\end{array}$ & $\begin{array}{l}\text { Tanggung jawab } \\
\text { provinsi dan } \\
\text { kabupaten/kota }\end{array}$ \\
\hline 2. & $\begin{array}{l}\text { Pelayanan } \\
\text { di tingkat } \\
\text { Satuan } \\
\text { Pendidikan } \\
\text { (13 indikator) }\end{array}$ & $\begin{array}{l}\text { Sepenuhnya } \\
\text { tanggung jawab } \\
\text { kabupaten/kota } \\
\text { (sering dianggap } \\
\text { tanggung jawab } \\
\text { sekolah saja) }\end{array}$ & $\begin{array}{l}\text { Tanggung jawab } \\
\text { kabupaten/kota } \\
\text { dan sekolah }\end{array}$ \\
\hline
\end{tabular}

Sumber: Juanda, et al. (2014).

Penggunaan DAK perlu diterapkan dalam kerangka pengeluaran jangka menengah berdasarkan proposal kegiatan daerah untuk mencapai standar pelayanan, minimal pada standar yang sudah ditetapkan kementerian teknis (SPM). Reformasi kebijakan ini menyebabkan petunjuk pelaksanaan (juklak) ataupun petunjuk teknis (juknis) berlaku minimal untuk tiga tahun anggaran.

\section{Perbaikan Penganggaran Hibah dan Bantuan Sosial}

Penganggaran hibah menurut regulasi

Permendagri No. 32 Tahun 2011 tentang pedoman pemberian hibah dan bantuan sosial yang bersumber dari APBD, bersifat aktif. Usulan hibah disampaikan oleh pihak yang akan menerima hibah. Namun mekanisme pemberian hibah oleh pemerintah bersifat tertutup karena tidak melalui proses pemberitahuan kepada masyarakat mengenai rencana pemberian hibah. Maka upaya yang dilakukan adalah perbaikan mekanisme penganggaran hibah agar lebih transparan dan akuntabel. Misalnya pemerintah daerah membuat pengumuman kepada publik mengenai usulan hibah yang akan diajukan untuk dianggarkan melalui APBD. Resiko sosial ada yang dapat diprediksi (systematic social risk) dan ada yang tidak dapat diprediksi. Perencanaan dan penganggaran bansos ditekankan pada resiko sosial yang dapat diprediksi. Sebagai contoh bansos dengan resiko sosial dapat diprediksi adalah "bantuan kematian". Besar alokasinya dapat ditentukan berdasarkan data histroris tingkat kematian penduduk di wilayah bersangkutan, sedangkan alokasi bansos yang tidak dapat diprediksi misalnya ditentukan maksimal sebesar 50 persen dari alokasi bansos yang dapat diprediksi. Pemerintah daerah disarankan membuat pengumuman ke masyarakat mengenai rencana penyaluran bansos, sehingga penganggarannya lebih transparan dan akuntabel.

\section{Perbaikan Mekanisme Pelaporan Pemerintah Daerah}

Terdapat tiga regulasi yang mengharuskan pemerintah daerah menyusun laporan pelaksanaan pembangunan dengan format dan tujuan yang berbeda-beda dengan substansi tujuan yang sama. Mekanisme pelaporan yang ada saat ini sangat memberatkan daerah. Peserta FGD menyarankan perlunya perbaikan regulasi dengan menyederhanakan sistem pelaporan yang dapat memenuhi kebutuhan pemeriksaan keuangan, kinerja, dan penyelenggaraan pemerintahan daerah. Solusi ini dapat dilakukan dengan mengintegrasikan Sistem Informasi Perencanaan Pembangunan Daerah (SIMREDA) dan Sistem Informasi Keuangan Daerah (SIMKEUDA) yang saat ini masih berjalan secara terpisah.

\section{SIMPULAN DAN SARAN}

\section{A. Simpulan}

Tulisan ini mengusulkan konsep belanja daerah berkualitas sebagai reformasi kebijakan desentralisasi fiskal di Indonesia. Kebijakan belanja berkualitas merupakan kebijakan yang mendorong pengelolaan keuangan daerah agar belanja dapat dialokasikan berdasarkan prioritas pembangunan daerah secara efisien dan efektif, tepat waktu, transparan, dan akuntabel. Mekanisme pembahasan APBD saat ini berpotensi menyebabkan terjadinya distorsi prioritas daerah, tidak tepatnya alokasi belanja, penyusunan, dan implementasi APBD tidak tepat waktu, sehingga belanja daerah menjadi tidak efektif dan efisien. Regulasi saat ini ikut menyebabkan pengelolaan 
keuangan daerah menjadi tidak transparan dan akuntabel.

Harmonisasi antara regulasi pengelolaan keuangan daerah dengan regulasi sektoral juga harus dilakukan. Disharmoni antarregulasi yang terjadi di sektor pendidikan telah menyebabkan pemerintah daerah gagal mengatasi masalah prioritas pendidikan dasar seperti penyediaan kekurangan guru dan kerusakan infrastruktur pendidikan dasar. Pemberian hibah dan bansos yang bersumber dari APBD masih memungkinkan penyalahgunaan anggaran, sehingga perlu perbaikan mekanisme perencanaan dan akuntabilitasnya. Disharmoni antarregulasi menggambarkan lemahnya koordinasi dan sinkronisasi kebijakan pemerintah pusat. Perbaikan dapat dimulai dengan penyederhanaan dan pengintegrasian sistem pembinaan, pengawasan, dan evaluasi pembangunan daerah yang saat ini masih berjalan secara terpisah pada masing-masing kementerian dan lembaga.

\section{B. Saran}

Konsep kebijakan pengelolaan keuangan daerah perlu diarahkan untuk mewujudkan belanja daerah yang berkualitas. Implementasi kebijakan tersebut disarankan melalui peningkatan kualitas rencana kerja dan penyederhanaan mekanisme pembahasan APBD. Penerapan kerangka pengeluaran jangka menengah terutama untuk urusan wajib pelayanan dasar dapat memangkas birokrasi implementasi anggaran seperti yang diatur setiap tahun dalam juknis yang selalu terlambat. Reformulasi pengalokasian DAK berdasarkan proposal kegiatan yang mendukung pencapaian standar pelayanan minimal sebagai bentuk implementasi anggaran berbasis kinerja dengan pendekatan bottom-up planning. Peningkatan kualitas belanja daerah juga memerlukan perbaikan regulasi dana hibah dan bansos, serta penyempurnaan sistem pembinaan, pengawasan, dan evaluasi pembangunan daerah. Saran dan rekomendasi ini perlu dimasukkan dalam revisi Undang-Undang No. 33 Tahun 2004 tentang Perimbangan Keuangan antara Pemerintah Pusat dan Pemerintahan Daerah.

\section{DAFTAR PUSTAKA}

\section{Buku}

ANTARA-AusAID. (2011). Laporan pengukuran kapasitas pengelolaan keuangan daerah di Provinsi NTB. Mataram: ANTARA-AusAID.
Bappenas. (2013). Analisis kesenjangan antarwilayah tahun 2013. Jakarta: Bappenas.

Bird, R. M. and Vaillancourt, F. (1998). Fiscal decentralization in developing countries. United Kingdom: Cambridge University Press.

BPS. (2012). Laporan Indeks Pembangunan Manusia tahun 2010-2011. Jakarta: BPS.

DJPK. (2009). Grand design desentralisasi fiskal Indonesia. Jakarta: DJPK Kementerian Keuangan RI.

DJPK. (2013). Deskripsi dan analisis APBD 2013. Jakarta: DJPK Kementerian Keuangan RI.

DJPK. (2014). Laporan pelaksanaan spending performance dalam mendanai pelayanan publik. Jakarta: DJPK Kementerian Keuangan RI.

Halim, A. (Eds). (2013). Manajemen keuangan sektor publik, problematika penerimaan dan pengeluaran pemerintah (Anggaran Pendapatan dan Belanja Negara/Daerah). Jakarta: Penerbit Salemba Empat.

Jaya, W. K. (2010). Kebijakan desentralisasi di Indonesia dalam perspektif teori ekonomi kelembagaan. Pidato Pengukuhan Jabatan Guru Besar dalam Ilmu Ekonomi Universitas Gadjah Mada. Yogyakarta: UGM Press.

Juanda, B., Handra, H., Auracher, T., Sitepu, B., dan Marthaleta, N. (2013). Penyusunan mekanisme Dana Alokasi Khusus (DAK) untuk pembiayaan Standar Pelayanan Minimal (SPM). Jakarta: DJPK Kementerian Keuangan RI.

Juanda, B., Halim, A., Azis, N., dan Kaiwai, H. Z. (2014). Evaluasi regulasi pengelolaan keuangan daerah dan pengaruhnya terhadap upaya peningkatan kualitas belanja daerah. Simanjuntak, R. A. dan Handra, H. (Eds). Jakarta: DJPK Kementerian Keuangan RI.

Litvack, J. and J. Seddon (Eds). (1999). Decentralisation briefing notes. Washington DC: World Bank Institute.

Ostrom, E. (2005). Doing institutional analysis digging deeper than markets and hierarchies. C. Menard and M. M. Shirlet (Eds.) Handbook of New Institutional Economics (pp. 819-848). Netherlands: Springer.

\section{Jurnal}

Akai, N. and Sakata, M. (2002). Fiscal decentralization contributes to economic growth: Evidence from state-level cross-section data for the United States. Journal of Urban Economics, 52, 93-108. 
Jaya, W. K. (2005). Disfunctional institutions in the case of local elite behaviour in decision making about local government budgets in Indonesia. Jurnal Ekonomi dan Bisnis Indonesia, 20(2), 189204.

Lin and Liu. (2000). Fiscal decentralization and economic growth in China. Economic Development and Cultural Change, 49, 1-29.

Lisna, V., Sinaga, B. M., Firdaus, M., dan Sutomo, S. (2013). Dampak kapasitas fiskal terhadap penurunan kemiskinan: Suatu analisis simulasi kebijakan. Jurnal Ekonomi Pembangunan Indonesia, 14(1), 1-26.

Nugraheni, D. dan Priyarsono, D.S. (2012). Kinerja keuangan daerah, infrastruktur, dan kemiskinan: Analisis kabupaten/kota di Indonesia 2006-2009. Jurnal Ekonomi dan Pembangunan Indonesia, 12(2), 148-167.

Suwana, A. F. and Sulistiani, E. H. (2009). Fiscal decentralization and regional disparities in Indonesia: A dynamic panel data evidence. Journal of Indonesia Economi and Business, 24(3), 328-336.
Xie, D., Zou, Heng-fu, and Davoodi, H. (1999). Fiscal decentralization and economic growth in the United States. Journal of Urban Economics, 45, 228-239.

\section{Sumber Digital}

Mendagri. (2012). Keterangan pemerintah atas Rancangan Undang-Undang tentang Pemerintahan Daerah. Diperoleh tanggal 3 April 2013 dari http://www.kemendagri.go.id /news/2012/04/03/keterangan-pemerintahatas-rancangan-undang-undang-tentangpemerintahan-daerah.

\section{Sumber Lain}

Anonymous. (2016, 25 April). Otonomi tak kunjung sejahterakan daerah. Pikiran Rakyat.

Juanda, B. (2016a, 25 April). Memperkuat otonomi daerah dalam menghadapi MEA. Investor Daily.

Juanda, B. (2016b, 4 Mei). Reformasi kebijakan desentralisasi fiskal upaya mendorong pertumbuhan dan mengurangi kesenjangan antardaerah. Radar Banten. 